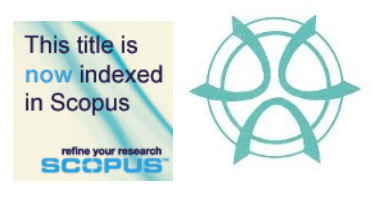

PLANNING MALAYSIA:

Journal of the Malaysian Institute of Planners

VOLUME 19 ISSUE 4 (2021), Page $72-82$

\title{
ACQUIRING ELEMENTS OF SOLAR FARM DEVELOPMENT'S APPROVAL CONSIDERATION IN JOHOR
}

\author{
Mohd Shahrizan Sahid ${ }^{1}$, Robiah Suratman ${ }^{2}$, Hishamuddin Mohd $\mathrm{Ali}^{3}$ \\ ${ }^{1,2,3}$ Faculty of Built Environment and Surveying \\ UNIVERSITI TEKNOLOGI MALAYSIA
}

\begin{abstract}
In order to fulfil the increasing energy demand, Malaysia aims to reduce carbon emission by 45 percent by 2030, and becomes fully carbon neutral by 2050 . However, promoting this energy has inevitably forced this new industry to face some drawbacks particularly related to land matters, especially solar farm development, which is still new in the country and does not have any proper guidance. As the control of land planning and development is under the responsibility of the State Authority as enshrined in Article 74 of the Federal Constitution, the implementation is different in each state due to different land policy known as the State Land Rules. Thus, selected respondents have been interviewed, and the findings have been acquired regarding the elements of solar farm development's approval consideration from the perspectives of land administrator, planner, and developer. This leads to a direction to standardize a legal framework of the land approval consideration for solar farm development especially in Johor.
\end{abstract}

Keywords: solar farming, land development approval, land use management, renewable energy

\footnotetext{
${ }^{1}$ PhD candidate at Universiti Teknologi Malaysia Email: shahrizan7@gmail.com
} 


\section{INTRODUCTION}

Solar farm does not have any specific definition, but it fundamentally generates electricity from solar radiation, and it is operating in a piece of land (Jones, 2014). Moreover, solar farm also predictably generates at least 5 Megawatt (MW) which is equivalent to the demand of 1,200 houses and requires at least 15 hectares of land; $30 \%$ of which is filled with about 20 thousand solar panels. Solar energy generation capabilities may vary according to locations due to the different capacities of solar radiation reception.

According to Sustainable Energy Development Authority (SEDA) (2017), solar radiation produces approximately $1,266 \mathrm{~W} / \mathrm{m}^{2}$ to the earth's atmosphere depending on the latitude, seasonality, and weather. Figure 1 shows the photovoltaic power potential in Malaysia, and this strategic position causes Malaysia to receive longer rays of sun radiation for around twelve hours, which produce solar energy through photovoltaic technology (Department of Meteorology, 2020; Manickam, 2017). There are several methods for generating solar energy around the world, i.e., ground- and roof-mounted, building integration or Building Integrated Photovoltaic (BIPV), and floating solar farm. SEDA has promoted solar energy through a variation of schemes and policies, but as for now, only New Net Metering (NEM), New Enhanced Dispatch Arrangement (NEDA), and Large-Scale Solar (LSS) are maintained (Cheah, 2021).

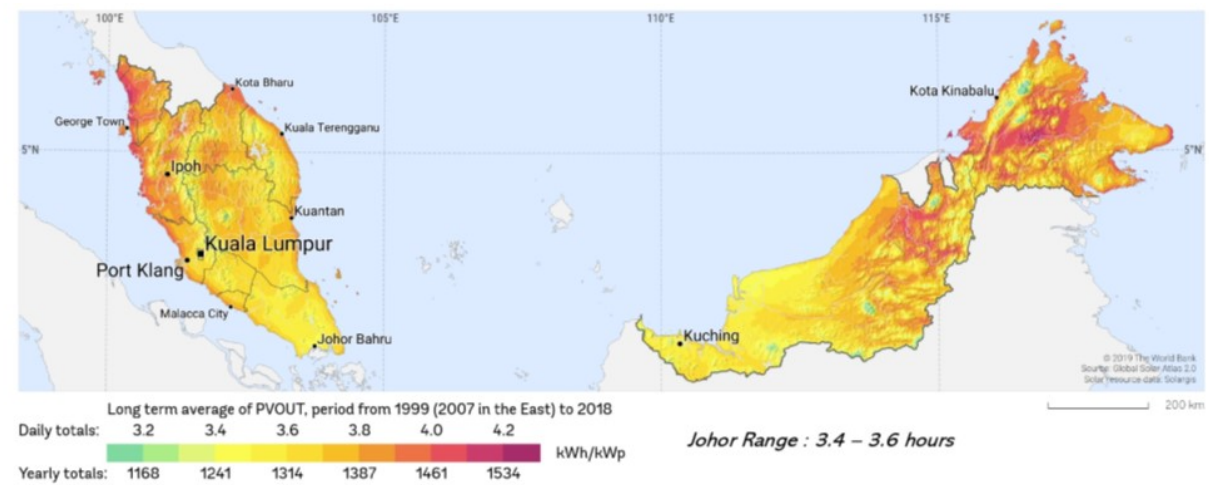

Figure 1: Photovoltaic Power Potential in Malaysia Source: Solargis, 2019

In order to promote the use of this potential energy in Malaysia, the allocation of land is needed to develop a solar farm. According to Hernandez (2015), solar energy generation requires a suitable site to reduce the economic and ecosystem impacts of the land. As the operation is temporarily permitted within 20 years (SEDA, 2017), it raises confusion among land administrators, 
Mohd Shahrizan Sahid, Robiah Suratman, Hishamuddin Mohd Ali

Acquiring Elements of Solar Farm Development's Approval Consideration in Johor

developers, and landowners when the generation of solar energy is categorised as industrial development (TNB, 2019), which is they were built on agricultural lands, and it is contradict with provision of Section 52 National Land Code 1965. Thus, this study determines how the land administrator or State Authority approves the development of precise elements for approval consideration.

From the previous studies, many elements and criteria were found and most of them came from planners' perspective, such as site selection and the potential of solar energy. Site selection for a solar power plant is a complex process because of the different safety, economic, environmental, and social needs that must be considered (Yun-na et al., 2013). Furthermore, the location with the best source of sunlight cannot always be selected because there are several other factors that play important roles in the selection of a suitable location specifically economic, environmental, and social factors (Van Harren et al., 2011). These include effects on land, landscape, and visual facilities; ecology and nature conservation; cultural heritage and historical environment; construction and highway traffic; safety; economic benefits; and potential economic and social impacts to the community. Although many local planning authorities clearly support the development of solar energy, but the full emphasis and use of decision-making models in giving full consideration to such issues are required (Tanavana et al., 2017).

Thus, Sindhu (2017) has grouped those elements into five main elements as a decision compiler known as political or legal, technical, environmental, social, and economy. Thus, this study was focused on political or legal' elements, specifically from the perspectives of land administrators, planners, and developers. These is including state government policies, regulatory bodies, land acquisition, and resettlement and rehabilitation. In terms of land administrators' or planners' consideration, the political factors include land category, development zoning, land conditions (express and implied conditions), methods of approval, and any other requirements for solar farm development's approval consideration. As the solar farm development is still new in the country, the land administrator does not have any proper guidelines especially in considering approval for the development. This leads to the findings of the study that is acquiring the elements of solar farm development approval consideration.

\section{RESEARCH BACKGROUND \\ Issues And Challenges from Current Practices}

Based on current practices in Malaysia, there are several methods of approval by the State Authority in developing solar farms. As the development of solar farm is temporary, the decision to use Special Permit is seen appropriate to support in promoting the solar development. However, it remains controversial among legal 
practitioners as some states direct developers to change the terms of the agricultural land.

The provisions of Section 52 of the National Land Code 1965 only state the types of land use in three categories, namely agriculture, building, and industry in the land title document and must be complied by landowners unless allowed by the State Authority through a change of land. According to the Sustainable Development Authority (SEDA) (2017), solar power generation operations are allowed in the short term of only within 20 years. Tenaga Nasional Berhad (2019) states that solar energy generation is similar to electric power plants and is categorized as industrial development. Thus, it triggers confusion among land administrators, landowners, and developers. However, if the land used is rented or leased for a period of time, then the original landowners do not have the intention to revoke the applications because the original agreement with the developers only allow them to use the land for solar development.

In addition, there is no clear legal provision for the development of these solar farms, thus causing some issues to arise. First, some landowners take the opportunity to develop solar farms on agricultural lands without changing express conditions of the lands which ultimately cause financial implications to the State Authority due to land tax collection differences where agricultural land tax is cheaper than industrial land tax. Moreover, the development of solar farms requires large areas that require the cooperation of several landowners (Sabo et al., 2017; Hui et al., 2009). No clear legal provision also makes landowners less confident to give up their lands to carry out solar farm development activities (Fthenakis \& Kim, 2009). Thus, land administrators need to be equipped with comprehensive and clear procedures and policies to support the development of solar farms that have great potentials in the future.

\section{Land Development Process and Procedure}

The development control in Peninsular Malaysia is implemented through two levels, namely the state level and the local level. At the state level in Peninsular Malaysia, the State Government is fully responsible for all matters including land use, land conversion, amalgamation, subdivision, and other matters related to land in respective states. At the local government level, the local authority is responsible for controlling the development in the planning area from technical aspects such as layout, building design, route system, and provision of public facilities.

Part of the planning function involves control over various development activities carried out by the public and institutions to create a healthy, safe, and harmonious environment. The activities carried out should be in line with the structural plan policies and local plan proposals. In terms of development, the principle practiced by the government is that no individual has an absolute right to his land instead of an exclusive right to a property. The absolute right to land 
Mohd Shahrizan Sahid, Robiah Suratman, Hishamuddin Mohd Ali

Acquiring Elements of Solar Farm Development's Approval Consideration in Johor

exists only on the part of the government when necessary to safeguard the public interest. This right is evident under the Town and Country Planning Act 1976 (Act 172) which prohibits a person from carrying out development activities or activities without permission from the local planning authorities unless existing activities have already existed before this act came into force

In carrying out development control, the provisions in the National Land Code Act 1965 (Act 56) and the Town and Country Planning Act 1976 (Act 172) are the basis for administration, control, and reference to land development practiced in the country (Yahya, 2010). Pursuant to Act 172, 'development' is defined as carrying out any building, engineering, mining, industrial, or any other similar work on, above, next to, or below ground, making a change in the use of a land or any - any part thereof or subdivide boundaries or annex the land. Apart from that, the Roads, Drains and Buildings Act 1974, the Environmental Quality Act 1974, and other related acts also refer to land development practices by relevant authorities.

Generally, the process of land development in Malaysia involves three main stages of planning or pre-construction, construction, and post-construction (Abdullah et al., 2011). The planning or pre-development stage involves the process of obtaining Planning Permission (PP) which is submitted to the One Stop Service Centre (OSC) subject to Subsection 19 (1) of Act 172, which is to obtain Planning Permission (PP) from the Local Authority (LA) before starting a development. Planning permission refers to permission granted, with or without conditions, to carry out development. This means that any development as stated in the development proposal (Section 21A) and layout plan (Section 21B) must submit a planning permission application to LA for approval. Planning permission approval is a mandatory statutory approval for applicants to commence development work. Therefore, any development carried out other than what is approved by LA pursuant to Section 20 or contrary to the stipulations stated in the District Local Plan is not allowed in accordance with the provisions of Section 18 (1) of Act 172.

Then, OSC will distribute the submitted PP applications to the technical departments for comments for the purpose of approval consideration. Usually, the approval is given by planning approving committee among the local authorities where the OSC is located. According to Manual of OSC 3.0 Plus (2019), there are twenty-two (22) representatives from technical departments and local authority's councillors who are the decision makers at the OSC, but it is depends on the development application. For example, in Johor, there are 10 technical departments involved in providing reviews. These include four internal departments from the Local Authority - Planning Department, Building Department, Engineering Department and Health Department, District Land Office, Irrigation and Drainage Department, Fire and Rescue Department, Public Works Department, Telekom Malaysia Berhad, and Tenaga Nasional Berhad 
(Suhailizan, 2019). This review will assist the OSC in setting the conditions for the purpose of approval. If the application is approved, then PP will be issued through the $\mathrm{C} 1$ Form. The $\mathrm{C} 1$ Form will be used as the basis and main reference for land related applications such as boundary breaking and changes in express conditions for the consideration and approval of the State Authority. Fundamentally, the land development application procedure engages five main stages that applicants must go through, as Table 1 follows:

Table 1: Main Stages for Land Development in Malaysia

\begin{tabular}{|c|l|l|}
\hline Stage & \multicolumn{1}{|c|}{ Description } & \multicolumn{1}{|c|}{ Legal Revision } \\
\hline 1 & $\begin{array}{l}\text { Application for Development Policy Approval } \\
\text { or land conversion approval }\end{array}$ & $\begin{array}{l}\text { Section 124 of the } \\
\text { National Land Code }\end{array}$ \\
\hline 2 & Application for planning permission & Section 21 (1) of Act 172 \\
\hline 3 & $\begin{array}{l}\text { Application for boundary subdivision/ } \\
\text { amalgamation/ subdivision }\end{array}$ & $\begin{array}{l}\text { Section 136 of the } \\
\text { National Land Code }\end{array}$ \\
\hline 4 & Application for building plan approval & Section 70 of Act 133 \\
\hline 5 & $\begin{array}{l}\text { Application for approval of Certificate of } \\
\text { Fitness for Occupation }\end{array}$ & $\begin{array}{l}\text { By-Law 27, Uniform } \\
\text { Building By-Laws 1984) }\end{array}$ \\
\hline
\end{tabular}

According to solar farm development, it also must go through the same process which involves physical changes to land for construction activities, as well as a substantial change (permanent) involving land use changes through the application of changing the land use category. A solar farm can be defined as a temporary land for activities with a maximum period up to 25 years.

\section{CASE STUDY}

This research concentrates on the elements of approval consideration of solar farm development including reviews from a planner and a developer. A case study has been selected which involves ZEC Solar Sdn Bhd, as it is the earliest solar farm application through Johor Land and Mines Office. It is located in Kota Tinggi District in Johor with estimated area of 140 acres, a Malay Reserve Land, with a combination of two plots of agricultural land, specifically palm oil plantation, that are about 20 to 30 years old in a clean, well-managed, and perfect condition. The soil conditions are steep, low, and hilly, and the soil type is of the yellow clay type. The north of the land is for electrical transmission, while in the south is for road reserve, east is for pipeline storage, and west is planted with palm oil. This development is estimated to produce 29 Megawatts (MW) and the area includes solar panels, solar equipment, control room, office, and other relevant related utilities. The layout of the power plant is shown in Figure 2. 
Mohd Shahrizan Sahid, Robiah Suratman, Hishamuddin Mohd Ali

Acquiring Elements of Solar Farm Development's Approval Consideration in Johor

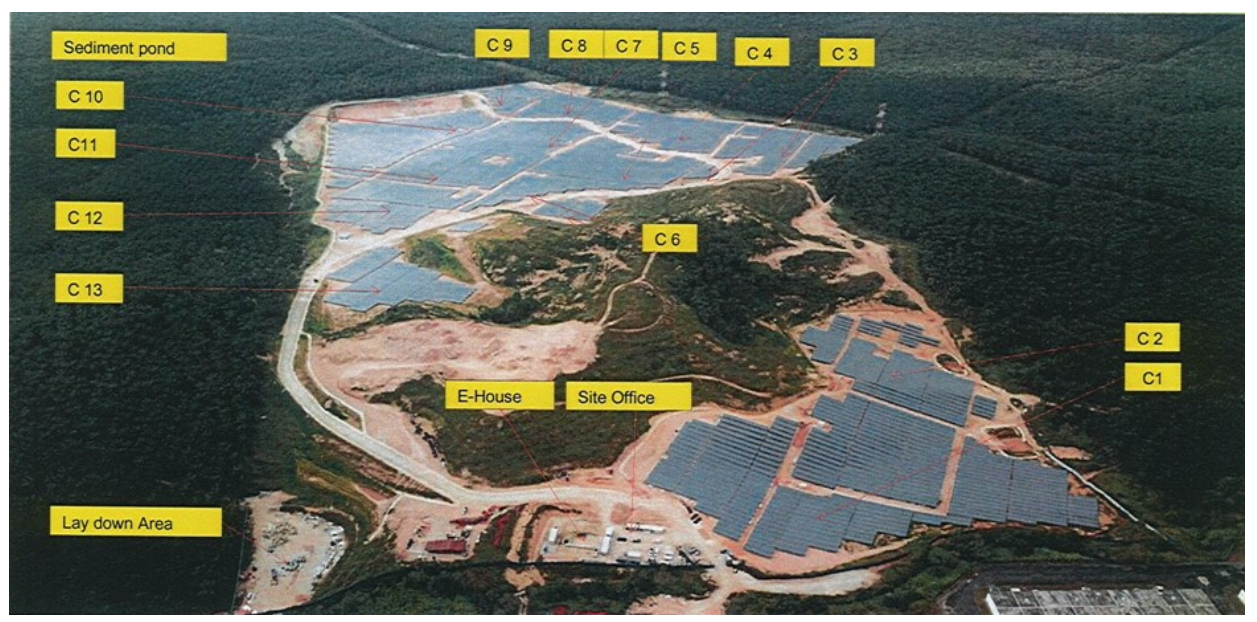

Figure 2: The Layout of YPJ Solar Farm Power Plant

\section{METHODOLOGY}

This study was conducted using open interviews with selected respondents, and they were selected using purposive sampling according to the research needs and purposes. In addition, the four respondents were selected since they were involved directly in the approval of this first solar farm in the state and telecommunication tower developments. Then, the data were analysed using content analysis based on data obtained interviewed with those respondents.

Table 2: List of Respondents in the study

\begin{tabular}{|c|c|c|}
\hline Respondents & Job Position & Agency \\
\hline R1 & $\begin{array}{c}\text { Chief Assistant Director of Disposal, } \\
\text { Enforcement \& Technical Division }\end{array}$ & $\begin{array}{c}\text { Johor Land and Mines } \\
\text { Office }\end{array}$ \\
\hline R2 & Land Administrator & $\begin{array}{c}\text { Kota Tinggi Land and } \\
\text { District Office }\end{array}$ \\
\hline R3 & Planner & $\begin{array}{c}\text { Kota Tinggi District } \\
\text { Council }\end{array}$ \\
\hline R4 & Developer & ZEC Solar Sdn Bhd \\
\hline
\end{tabular}

\section{RESEARCH FINDINGS}

Based on data obtained from the interviews, all respondents have responded on their scopes respectively. As mentioned above, this study focused on the elements of solar farm development's approval consideration. Based on the interviews, a Kota Tinggi District Council (MDKT) representative (R3) has responded as follows. 
R3: “...application of Planning Permit was submitted to Kota Tinggi District Council (MDKT) and reviews from related technical department have been made. We do not have any issue due to the application. For example, Department of Engineering MDKT put some conditions towards the applications, that are the applicants need to submit building plans, earthwork plans, roads and drainage, as well as street lighting plans. In addition, all forms of temporary construction work on the site must obtain MDKT approval and all permits must be clarified in accordance of Planning Permission that has been given ..."

Next, the development needs permission from land administrators. As this solar farm development has no specific guidelines in the state, permission has been done through the District Land Office and Johor Land and Mines Office.

R1: “...as the case study area is over than 10 acres, the approval might be considered by Johor Land and Mines Office as stated in National Land Code 1965 and Circular No. 2/1985. For now, we are using the telecommunication tower application as a benchmark of the elements of approval consideration in solar farm development. There are two reasons why it became the benchmark for the development. First, the telecommunication tower and solar farm are a temporary development. Second, both are built in agricultural land without land conversion. Due to this fact, we are using Special Permit to approve the development through two laws that are Section 115 (4) (f) (g) National Land Code and Johor Land and Mines Office Circular Number 3/2006."

Figure 3 illustrates the shared elements between telecommunication tower's and solar farm development's approval consideration.

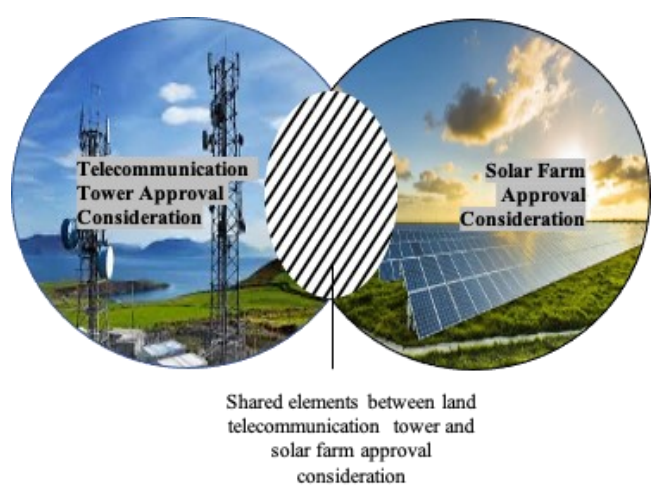


Mohd Shahrizan Sahid, Robiah Suratman, Hishamuddin Mohd Ali

Acquiring Elements of Solar Farm Development's Approval Consideration in Johor

Figure 3: Shared elements between telecommunication tower and solar farm approval consideration.

R2: "the elements of approval consideration are same as other development, but since it is a new development in the state, it needs some references especially from other states. We considered elements are who are the applicants whether they are landowners or developers, site area including the surroundings, land category, restriction, and conditions including zoning and title, technical reviews due to the application, and fee rate of the development. In addition, the application's approval consideration can be easier if the applicants have the certificate from Energy Commission (ST) and Planning Approval from local authority..."

According to the case study, the developer and landowner are different entities. But the landowner has leased the land to the developer for 25 years for the purpose of solar farm development.

R1: "we have given Special Permit to the landowner as provided in Section 115 (4) (f) (g) National Land Code 1965 that give flexibility to State Authority to allow the use of agricultural land for nonagricultural purposes other than agriculture to be included in the State Land Rules. This method is also stated in Rule $38 \mathrm{D}$ of the Johor Land Rules and is read together with Circular Number 1/2006 Director of Johor Land and Mines Office... this Special Permit will be expired by 31 December and must be renewed every year for maximum period for 25 years. However, the permit may be revoked immediately without any compensation if the licensee violates any provision subject to the district land administrator."

The issuance of Special Permit on the agricultural land is in Johor, with Circular No. 3/2006 listing down only two types of use. First, the management of matter relating to the telecommunication tower or structure. Second, the management of matters relating to the use of agricultural land for non-agricultural purposes. The first purpose involves government land, agricultural land, and building structure, while the second purpose involves private agricultural land. In connection with that, the R4 has identified an issue due to rate of fee for solar farm development.

R4: "... according to the issuance of the Special Permit, the rate of fee for telecommunication tower is RM 80 per 100 meter square feet... It was inappropriate. Moreover, we need to make payment for the Special Permit including trust fees every year not including other 
maintenance cost... It raised some issues that the fees are just suitable for a small development like telecommunication tower instead of solar farm development that requires a large area... we are bound with bank agreement for 15 years and the lease with landowner for 25 years, so the estimated profit margin is small. Due to that, we have submitted an appeal to the Johor Land and Mines Office to review the rate of payment of this special permit as it affects the cash flow of developers, especially this development is still in its early stages and we still need time to get a return on investment that has been issued..."

Based on the findings above, the elements of solar farm development approval consideration have been made based on benchmark study that is telecommunication tower development. The land administrator considered of land ownership, the applicant, land category, land restriction and conditions including zoning of the land. Hence, the planner considered about technical reviews and the developer considered of special permit rate of the development. However, the Special Permit rate that offered by the land administrator arise profit margin issue to the developer. The fee seems unfitting with this kind of development because it covered a large amount of area compared to telecommunication tower that use just a small area. Thus, the land administrator has been combined those perspective to make the best decision towards solar farm development in terms of approval consideration.

\section{CONCLUSION}

In brief, the great potential for solar farm development as alternative energy resources in the country must be highlighted by the government. Due to this kind of development is still new in the country especially in Johor, the land administrator must be equipped with comprehensive and relevant land policy and procedures. The elements of approval consideration have been made based on the similar practise as benchmark that is development of telecommunication tower. Besides that, thoughts from other related parties including planners, developers, and landowners must be a concern by land administrators to promote the best decision especially in considering approval of solar farm development.

\section{ACKNOWLEDGEMENTS}

This research paper is impossible without exceptional support from various parties including Universiti Teknologi Malaysia, supervisors, colleagues, and respondents (land administrator, planner, and developer). The enthusiasm, knowledge, and exacting attention from them have been an inspiration for us and derive our work on track till the end. Respect and appreciation are also expressed to those who have contributed to this research. 
Mohd Shahrizan Sahid, Robiah Suratman, Hishamuddin Mohd Ali

Acquiring Elements of Solar Farm Development's Approval Consideration in Johor

\section{REFERENCES}

Abdullah, W. S. W., Osman, M., Kadir, M. Z. A. A., \& Verayiah, R. (2019). The Potential and Status of Renewable Energy Development in Malaysia. Energies. https://doi.org/10.3390/en12122437

Fthenakis, V., \& Kim, H. C. (2009). Land use and Electricity Generation: A Life-Cycle Analysis. Renewable and Sustainable Energy Reviews, 13(6-7), 1465-1474.

Hernandez R, Easter S, Murphy-Mariscal M, Maestre F, Tavassoli M, Allen E, et al. Environmental impacts of utility-scale solar energy. Renew Sustain Energy Rev 2014; 29:766-79.

Jabatan Kerajaan Tempatan (2019). Manual OSC 3.0 Plus Proses dan Prosedur Cadangan Pemajuan Serta Pelaksanaan Pusat Setempat (OSC). Kementerian Perumahan dan Kerajaan Tempatan Putrajaya.

Johor Land and Mines Office Circular No. 3/2006.

Johor Land Rules 1966.

Jones, P., Hillier, D., \& Comfort, D. (2014). Solar farm development in the United Kingdom. Property Management.

Maidin, A. J. (2012). Role of Land Use Planning in Improving Public Health. Available at SSRN 2015083.

Malaysia (1965). Kanun Tanah Negara 1965.

National Land Code (NLC) 1965.

Sabo, M. L., Mariun, N., Hizam, H., Mohd Radzi, M. A., \& Zakaria, A. (2016). Spatial energy predictions from large-scale photovoltaic power plants located in optimal sites and connected to a smart grid in Peninsular Malaysia.

Seksyen Perundangan Tanah (2014). Laporan Kajian Prosedur Siri 2: Pengeluaran Permit Khas Penggunaan Sementara Tanah Pertanian Bagi Maksud Yang Tidak Berkaitan Pertanian: Praktis Negeri Johor.

Sindhu, S., Nehra, V., \& Luthra, S. (2017). Investigation of feasibility study of solar farms deployment using hybrid AHP-TOPSIS analysis: Case study of India. Renewable and Sustainable Energy Reviews, 73, 496-511.

Singh, A., Vats, G., \& Khanduja, D. (2016). Exploring tapping potential of solar energy: Prioritization of Indian states. Renewable and Sustainable Energy Reviews, 58 , 397-406.

Sustainable Energy Development Authority Malaysia (SEDA). Overview of SEDA; 2011. http://www.seda.gov.my/ [Accessed 2 Disember 2019].

Van Haaren, R., \& Fthenakis, V. (2011). GIS-based wind farm site selection using spatial multi-criteria analysis (SMCA): Evaluating the case for New York State. Renewable and sustainable energy reviews, 15(7), 3332-3340.

Wu, Y., \& Wang, Z. (2017). The decision-making of agriculture \& solar complementary roof power generation project in rural area. Energy Procedia, 105, 3663-3672.

Yunna, W., \& Ruhang, X. (2013). Current status, future potentials and challenges of renewable energy development in Gansu province (Northwest China). Renewable and sustainable energy reviews, 18, 73-86.

Received: $19^{\text {th }}$ August 2021. Accepted: $10^{\text {th }}$ November 2021 